\title{
The transport of iron and copper across the cell membrane: different mechanisms for different metals?
}

\author{
BY HARRY J. MCARDLE \\ Department of Child Health, Centre for Research into Human Development, Ninewells Hospital \\ and Medical School, Dundee DDI 9SY
}

Iron and copper are both essential elements and deficiencies in either lead to a wide variety of symptoms. They also appear to be linked to each other biologically. One of the most characteristic hallmarks of $\mathrm{Cu}$ deficiency is a hypochromic, microcytic anaemia. The mechanism involved has not been worked out, but it seems that $\mathrm{Cu}$, especially and perhaps exclusively as ceruloplasmin (EC 1.16.3.1), is necessary to maintain the flow of Fe through the hepatocyte (for a recent review, see Linder, 1991).

So much work has been done on the steps involved in Fe uptake that the number of examples used to illustrate any point has been restricted. Since the mechanism is essentially the same in all tissues studied thus far, the present discussion will use the placenta as the major example. Information gained from other tissues and cell types will be discussed where appropriate, however. In contrast, since little is known about $\mathrm{Cu}$ transport, data from a variety of different cell types will be discussed.

$\mathrm{Fe}$ in plasma is almost exclusively carried on transferrin (Tf). Tf is a serum glycoprotein, molecular weight about 80000 . It can carry two Fe atoms per molecule, which it binds in two extremely-high-affinity sites, one in the $\mathrm{N}$-terminal domain and the other in the C-terminal domain (for a recent review, see de Jong et al. 1990). Tf is the major source of $\mathrm{Fe}$ for most cells, although there is evidence that some cells, especially in human and guinea-pig, can utilize the Fe carried in serum ferritin (Blight \& Morgan, 1987; Lamparelli et al. 1989).

Most of the plasma $\mathrm{Cu}$ is also protein bound. The majority is associated with ceruloplasmin, an $\alpha$-globulin which has a sky-blue colour (hence the name) (Holmberg \& Laurell, 1947, 1948). The $\mathrm{Cu}$ is incorporated into the protein in the liver. There are six or seven $\mathrm{Cu}$ atoms per molecule (Messerschmidt \& Huber, 1990), none of which are readily exchangeable. They are found as three types: I, II and III; respectively, these are the 'blue' $\mathrm{Cu}$ (type I), $\mathrm{Cu}$ attached to histidyl imidazoles similar to the low-molecular-weight histidine-Cu complexes (type II), and the type III $\mathrm{Cu}$, a pair forming a diamagnetic complex (Calabrese et al. 1989). In vitro, only the blue $\mathrm{Cu}$ can be exchanged. This requires the presence of an oxidizing agent, such as vitamin $\mathrm{C}$, and $\mathrm{Cu}$ with which to exchange. Removal of the other $\mathrm{Cu}$ atoms necessitates very harsh treatment (Herve, 1985; Winyard et al. 1989). In addition to ceruloplasmin, significant (perhaps as much as $20 \%$ ), and probably biologically important amounts of $\mathrm{Cu}$ are found attached to a specific site on the N-terminal end of albumin (Lau \& Sarkar, 1971) and to amino acids, primarily histidine (Harris \& Sass-Kortsak, 1967; Neumann \& Sass-Kortsak, 1967). A high-molecular-weight plasma protein, transcuprein, has been described by Linder and co-workers (Weiss et al. 1985; Wirth et al. 1985) which may also be involved in $\mathrm{Cu}$ uptake, especially by hepatocytes. Neither $\mathrm{Cu}$ nor Fe are present as the free ion. 


\section{PLACENTAL FE UPTAKE}

The transfer of Fe from mother to fetus can be considered as occurring in three stages: uptake across the placental membrane into the placental cell, transfer across the cell and release into the fetal circulation. In the present review, neither the transplacental carriage of $\mathrm{Fe}$, nor the release of the metal to the fetal circulation will be examined, but the discussion will be restricted only to uptake. Similarly, neither $\mathrm{Cu}$ effiux nor transcellular $\mathrm{Cu}$ transport will be considered, concentrating only on $\mathrm{Cu}$ uptake into the cell.

Tf binding to the $T f$ receptor. The first stage in uptake is the binding of $\mathrm{Tf}$ to the $\mathrm{Tf}$ receptor on the chorionic microvilli at the maternal surface of the placenta.

The concept of a receptor for Tf was first suggested for reticulocytes by Jandl \& Katz (1963). Abundant evidence was provided for the existence of a receptor, but despite vigorous attempts, the receptor eluded isolation (for a review, see Morgan, 1981). Trowbridge \& Omary (1981) reported that a monoclonal antibody raised against membranes of a human leukaemic cell line was immunoreactive against a protein they showed to be the transferrin receptor (TfR) and the protein sequence has now been elucidated (McClelland et al. 1984). TfR is a glycoprotein with a molecular weight of 190000 , consisting of two identical dimers, linked by disulphide bridges and with the $\mathrm{N}$-terminals inside the cell.

Diferric Tf binds to the receptor with an affinity variously estimated as being between 106/M and 10\%/M (Bleil \& Bretscher, 1982; Harding et al. 1983; Iacopetta \& Morgan, 1983; McArdle et al. 1984b; Page et al. 1984; Bierings et al. 1988; de Jong et al. 1990). No clear explanation has been found for the different estimates, but it may be relevant that 'normal' cells, such as reticulocytes and primary cultures of placenta and liver, have a lower affinity than transformed or permanent cell lines.

Binding is $\mathrm{pH}$ dependent, with the diferric Tf having a high affinity at $\mathrm{pH} 7.4$ and a low one at $\mathrm{pH} 5 \cdot 5$. At lower $\mathrm{pH}$ values, the affinities are reversed. The biological relevance of this observation will be discussed later (p. 201). The number of binding sites varies from cell to cell, with dividing cells usually having higher numbers than quiescent cells (Musgrove et al. 1984).

Internalization of the $T f-T f R$ complex. Following binding, the Tf-TfR complex is internalized. The process involves accumulation into coated pits, followed by sealing into a coated vesicle (Harding et al. 1983; Hopkins, 1983; Hanover et al. 1985). The vesicle, which can contain different receptors and their ligands, then goes through a complex sorting process. The mechanisms involved in the sorting are outwith the scope of the present review but are outlined in de Jong et al. (1990).

Internalization of the $\mathrm{Tf}-\mathrm{TfR}$ complex as a necessary precursor to $\mathrm{Fe}$ accumulation was first suggested in 1969 (Morgan \& Appleton, 1969) and, after some debate, has now been accepted as the major way in which Tf is processed (Bleil \& Bretscher, 1982; Harding et al. 1983; Hopkins \& Trowbridge, 1983; Iacopetta \& Morgan, 1983). Alternative pathways may also operate in the liver, where 'non-specific' Tf and Fe uptake can become quantitatively important (e.g. see Morley \& Bezkorovainy, 1985; Trinder et al. 1990).

In the placenta, internalization into coated vesicles was indirectly demonstrated by Booth \& Wilson (1981), who isolated the vesicles from human placenta and showed that they contained Tf and immunoglobulin G. Further support was provided by Pearse (1982). Direct evidence that placental cells operate the same mechanism as other cell 
types had to wait, however, until placental cells were grown in culture and $\mathrm{Tf}$ and $\mathrm{Fe}$ uptake measured under these controlled and controllable conditions.

This was first accomplished by our group in 1984 (McArdle et al. 1984a, 1985) using rat placental cells. The results obtained were, in essence, the same as those described for other cell types. Since then, several groups have refined the culture process, and data has now been presented for cultured human placental cells, both cytotrophoblast and syncytiotrophoblast (Bierings et al. 1988; Bierings, 1989; Douglas \& King, 1990). In rat placental cells the ratio of receptors on the surface:those inside the cell was lower than in other cells; $10 \%$ internalized at any one time as opposed to $50 \%$ (Bierings, 1989) or $60 \%$ (Douglas \& King, 1990) in human trophoblast cells in culture, $70 \%$ in human fibroblasts (Wiley \& Kaplan, 1984) and up to $80-90 \%$ in reticulocytes and erythrocyte precursors (Morgan, 1981).

$\mathrm{Fe}$ release from $\mathrm{Tf}$. Following internalization into vesicles, the $\mathrm{pH}$ decreases to between 5.5 and 6.4 (van Renswoude et al. 1982; Paterson et al. 1984). The mechanism involved in the decrease is uncertain, but it is likely that a hydrogen ion pump is activated. The decrease has several effects. First, the receptor undergoes a conformational change resulting in self association, which in turn decreases sensitivity to protease activity (Turkewitz et al. 1988). Second, the decrease results in a drop in the affinity of $\mathrm{Tf}$ for its $\mathrm{Fe}$, so that, in the presence of a chelator, citrate or EDTA, for example, the $\mathrm{Fe}$ can be removed for transfer across the vesicle membrane and intracellular processing. Third, apoTf has a high affinity for the receptor at low $\mathrm{pH}$. Thus, conversion of the Tf to the apoprotein means that it stays bound to the receptor, again increasing protection against proteolysis and allowing recycling to the membrane surface (Dautry-Varsat et al. 1983; Rao et al. 1983; Paterson et al. 1984).

There is some evidence that, in the reticulocyte and placenta at least, removal of the metal is either accompanied by or preceded by, reduction of the ferric ion to ferrous ion. $\mathrm{Fe}^{2+}$ chelators such as $2,2^{\prime}$-bipyridine and 1,10 phenanthroline, which block uptake of $\mathrm{Fe}$ from Tf, complex the Fe while it is still within the vesicles in reticulocytes (Baker et al. 1985) and placental cells in culture (Wong et al. 1987).

There is limited evidence that the transfer of Fe across the vesicle membrane is a protein-mediated process, and Morgan (Bowen \& Morgan, 1987) has suggested that this protein is defective in the Belgrade rat, which has a genetic deficiency resulting in anaemia.

Exocytosis of the Tf-TfR complex. Following uptake into endosomes, most ligands are degraded. As discussed previously, however, Tf remains attached as the receptor is returned to the membrane surface where the apoTf is released. The TfR is, thus, free to undergo another cycle, and it has been estimated to perform as many as 300 cycles before being broken down (Omary \& Trowbridge, 1981).

Cycling continues whether or not the receptor is occupied (Hopkins \& Trowbridge, 1983). The rate of cycling of the receptor is different for different cell types and appears to depend on the Fe requirement of the cell. In reticulocytes, cycling is about $3 \mathrm{~min}$, but can be as much as $10 \mathrm{~min}$ in other cells (Karin \& Mintz, 1981; Hopkins, 1983; Hopkins \& Trowbridge, 1983; Iacopetta \& Morgan, 1983; McArdle et al. 1984a).

\section{CELLULAR CU UPTAKE}

Since so little is known about $\mathrm{Cu}$ transfer across the placenta, it will not be possible to concentrate on this or any other cell type in particular. This part of the review, therefore, 
will draw on data derived from a variety of cell types. At the moment, there appears to be two major mechanisms operating: one system for hepatocytes and another for non-hepatocyte cells. However, as the following discussion will show, at the molecular level the uptake processes may be very similar.

$\mathrm{Cu}$ uptake by hepatocytes. Following transport across the gut, $\mathrm{Cu}$ is first associated with albumin. The protein has a $\mathrm{Cu}$-specific binding site located at the $\mathrm{N}$-terminal (Rakhit \& Sarkar, 1981). Critical to the specificity of this site is a histidyl residue at the third amino acid position (Lau et al. 1974). In those species where the histidine has mutated to tyrosine (dogs and pigs, for example), the specificity of binding has been lost (Appleton \& Sarkar, 1971; I. Bremner, personal communication).

Mechanism of uptake. $\mathrm{Cu}$ uptake is a carrier-mediated process not dependent on metabolic energy (Weiner \& Cousins, 1980, 1983; Darwish et al. 1983; McArdle et al. 1988). Michaelis constant $\left(K_{m}\right)$ values vary between 4 and $20 \mu \mathrm{M}$ and the maximum velocity $\left(V_{\max }\right)$ shows similar variation. Using hepatocytes in suspension culture, Ettinger's group (Darwish et al. 1983; Schmitt et al. 1983) showed that uptake was probably from the $\mathrm{Cu}$-histidine $\left(\mathrm{CuHis}_{2}\right.$ ) fraction of plasma, an observation confirmed by ourselves (McArdle et al. 1988). The histidine is not itself taken into the cell and dissociation of the $\mathrm{CuHis}_{2}$ complex takes place at the membrane surface.

The role of albumin in Cu uptake by hepatocytes. Ettinger and co-workers (Schmitt et al. 1983; Darwish et al. 1984) also showed that the uptake was 'inhibited' by adding albumin. van den Berg \& van der Hamer (1984) obtained similar results and further demonstrated that the albumin: $\mathrm{Cu}$ ratio was important. When high ratios were present, adding extra albumin made little difference, while at lower ratios the 'inhibition' was more marked. While we agree with the data, however, I believe that the use of the word 'inhibited' is not a good one. The serum albumin concentration is around $600 \mu \mathrm{M}$ and the maximum exchangeable (i.e. non-ceruloplasmin) $\mathrm{Cu}$ concentration is no more than 2 $\mu \mathrm{M}$. Thus, under physiological conditions, the ratio is such that the maximal 'inhibition' would always be present.

Mixing albumin with $\mathrm{Cu}$ at $\mathrm{pH} 7.4$ results in labelling the protein not only on the high-affinity site, but also on other sites on the protein (Breslow, 1964). In order to label the protein exclusively on the specific site, it is necessary either to use high albumin:Cu ratios, to leave the two together for a considerable period of time, or to mix at $\mathrm{pH} 5.5$ and then raise the $\mathrm{pH}$ to 7.4 . This fact was exploited to study the uptake of $\mathrm{Cu}$ by hepatocytes more closely. It was shown that if all the $\mathrm{Cu}$ was on the specific site, which would probably not be the case in the experiments mentioned previously, uptake was higher than if it was on lower-affinity sites (McArdle et al. 1990). The effect was specific for albumins with the specific binding site, since dog albumin, which has no histidine at position 3, did not show any pH-dependent effect. Further, if histidine was added, causing the formation of the highest-affinity $\mathrm{Cu}$-histidine-albumin (CuHisAlb) complex (Lau \& Sarkar, 1971) then uptake was maximal (McArdle et al. 1990).

Conclusions. All these findings can be reconciled by the following hypothesis. It is probable that, at the molecular level, all three complexes look similar, with the $\mathrm{Cu}$ atom coordinating with the imidazole- $\mathrm{N}$ of the histidine residues and the rest of the molecule being relatively unimportant (McArdle et al. 1990). The $\mathrm{Cu}$ is removed from the complex (see p. 204) and transferred to the cell separately.

$\mathrm{Cu}$ uptake by non-hepatocyte cells. Which substrate is recognized by the transporter? When $\mathrm{Cu}$ is transported across the gut, it appears first bound to albumin. Most of the $\mathrm{Cu}$ 
is taken up by the liver, but as much as $40 \%$ can pass the portal system (Danks, 1988). Thus, in systemic blood, Cu exists as ceruloplasmin (synthesized in the liver), from which it cannot readily be removed, and an exchangeable pool, comprising $\mathrm{Cu}$-albumin (CuAlb), $\mathrm{Cu}$-amino acids, primarily $\mathrm{Cu}$-histidine (CuHis 2 ) (Harris \& Sass-Kortsak, 1967) and transcuprein (Weiss et al. 1985; Wirth et al. 1985). Any or all these, as well as metallothionein, which appears in small but significant amounts in plasma (Mehra \& Bremner, 1983), could be the substrate for uptake.

$\mathrm{Cu}$ uptake from ceruloplasmin. Findings were presented from the 1960s onward (for review, see Owen, 1980) suggesting that ceruloplasmin was a likely substrate for uptake. However, this possibility was complicated by several factors. Ceruloplasmin has several other roles in the body. It is an enzyme (Gutteridge, 1983) and an acute-phase protein (Aldred et al. 1987). Serum levels are elevated by steroids and rise during pregnancy (Danks, 1988). Finally, Frieden (1980) showed that ceruloplasmin had a central role in the liver in Fe mobilization. Several workers used these findings as part of the argument against a transporter role for ceruloplasmin: how could such a multi-functional protein also have a role as a transporter?

Nonetheless, many of the findings were compelling. The changing concentrations of ceruloplasmin could well be related to changing demands of the different tissues. $\mathrm{Cu}$, and hence ceruloplasmin, may have a role in the acute-phase response and the increase during pregnancy could be related to the increased $\mathrm{Cu}$ requirement of the developing fetus. Experimental evidence for a role for ceruloplasmin was first presented by Owen (1980) and Marceau \& Aspin $(1972,1973)$ who showed that ${ }^{67} \mathrm{Cu}$ was accumulated in different tissues following injection of the labelled protein. Linder \& Moor (1977) showed that both $\mathrm{Cu}$ from ceruloplasmin and the protein itself were accumulated in the heart and other organs of the rat.

Dameron \& Harris $(1987 a, b)$ showed that $\mathrm{Cu}$ from ceruloplasmin could be not only taken up by aortic endothelial cells, but that the $\mathrm{Cu}$ was incorporated primarily into $\mathrm{Cu}, \mathrm{Zn}$ superoxide dismutase (EC 1.15.1.1). However, they showed that $\mathrm{Cu}$ from albumin and amino acids could also be incorporated into the enzyme.

In K562 cells, an erythroleukaemic cell line, there was strong evidence for a role for ceruloplasmin during differentiation. Percival \& Harris $(1989,1990)$ demonstrated that the amount of ceruloplasmin bound to the cells went up markedly when the cells were induced to differentiate with hemin. The number of sites increased to a maximum at about $72 \mathrm{~h}$ and, interestingly, the number of TfR decreased as the ceruloplasminbinding-site numbers increased (Percival \& Harris, 1988). $\mathrm{Cu}$ was only accumulated at $37^{\circ}$ and not at $4^{\circ}$ and was found first in a vesicular fraction separate from the protein moiety of the ceruloplasmin and later associated with superoxide dismutase. There was no evidence that the protein itself was either internalized or taken into the cell at all.

Finally, our group adopted the approach that if other plasma $\mathrm{Cu}$ transporters could be excluded, whatever was left had to be the substrate for uptake. Accordingly, we demonstrated that albumin was not involved in Cu uptake in fibroblasts (McArdle et al. 1987), a view supported by others (Laurie \& Pratt, 1986) and further showed that histidine also acted as an inhibitor, the degree of inhibition being related to the amount of amino acid present. The data obtained could only be explained if it was assumed that free (i.e. ionic) $\mathrm{Cu}$ was the substrate for uptake (McArdle et al. 1987). This is extremely unlikely in vivo, so that it was concluded that ceruloplasmin was indeed a very plausible carrier of $\mathrm{Cu}$ for uptake into cells. 
$C u$ uptake from the exchangeable pool. At the same time, however, findings were being presented to suggest that low-molecular-weight $\mathrm{Cu}$ was also important in transport. Herd et al. (1987) had shown that $\mathrm{HiSCu}_{2}$ could be taken up by human lymphoblasts. Uptake from low-molecular-weight complexes has been used for many years to identify cells from patients with Menkes' disease, a genetic disorder of $\mathrm{Cu}$ metabolism (Danks, 1988; van den Berg et al. 1990a).

Recently, it has been shown that $\mathrm{Cu}$ from $\mathrm{CuHis}_{2}$ can cross the placental barrier, and that the transport shows developmental change (McArdle \& Erlich, 1991). This work has been extended and it has been demonstrated that vesicles isolated from human placenta accumulate Cu from CuHis 2 (McArdle \& van den Berg, 1991).

Barnea et al. (1988) had been studying hormone release from median eminence and showed that $\mathrm{Cu}$, presented as $\mathrm{CuHis}_{2}$, could stimulate release. They studied this process carefully and found that there were two $\mathrm{CuHis}_{2}$ transport systems, a high-affinity one which operated at low $\mathrm{Cu}$ :His ratios $(1: 2000)$ and a low-affinity one which operated at higher ratios $(1: 20)$. The effect is specific for L-histidine, suggesting that there may be a biological relevance to the observation. More recently, they have examined the effect of different amino acids on uptake, and have compiled a list with relative affinities. From the data, they have been able to suggest that the $\mathrm{Cu}$ recognition site requires at least two $\mathrm{N}$ and possibly three $\mathrm{N}$ co-ordinating with the metal (Katz \& Barnea, 1990).

Release of $\mathrm{Cu}$ from its binding complex. The release of $\mathrm{Cu}$ from the complex can be accomplished by reducing the cupric ion to cuprous ion. Several pieces of evidence suggest that this occurs. Percival \& Harris (1989) have shown that ascorbic acid increases uptake of $\mathrm{Cu}$ into $\mathrm{K} 562$ cells and that $\mathrm{Cu}^{+}$chelators block the effect. $\mathrm{Cu}^{2+}$ chelators, in contrast, have no effect. Similar findings have been obtained in mouse hepatocytes and it has also been shown that vitamin $E$ acts to inhibit the stimulation (H. J. McArdle and S. M. Gross, unpublished results). Further, vitamin $\mathrm{C}$ supplementation in rats results in an increased retention of $\mathrm{Cu}$, possibly in the liver (van den Berg et al. 1990b). A membrane reductase has been described which could fulfil this function (Sun et al. 1987).

Identification of a ceruloplasmin-Cu-binding protein. A ceruloplasmin receptor has now been described in a variety of cell types. Stevens et al. (1984) showed specific binding in membrane fragments from aortic endothelia and Barnes \& Frieden (1984) have shown that they exist in erythrocytes. They isolated a protein of $60 \mathrm{kDa}$ molecular weight which may be a ceruloplasmin receptor. These receptors have been carefully studied by Saenko \& Yaropolov (1990) who have shown them to be possibly part of the glycophorin complex of the erythrocyte.

Using membrane fragments from different tissues, and cultured cells, Orena et al. (1986) showed that ceruloplasmin bound specifically and that $\mathrm{Cu}$ could be accumulated from the protein, but also showed that low-molecular-weight $\mathrm{Cu}$ complexes such as $\mathrm{Cu}$-nitrilotriacetate (NTA) could interfere with uptake. We have made similar observations in human placental vesicles (McArdle \& van den Berg, 1991).

These observations can be put together to build a model for $\mathrm{Cu}$ uptake in nonhepatocyte cells which is essentially the same as for hepatocytes.

\section{A SINGLE HYPOTHESIS FOR CU UPTAKE IN MAMMALIAN CELLS}

This hypothesis is based on the fact that the molecular appearance of most $\mathrm{Cu}$ complexes are similar. In most cases, the $\mathrm{Cu}$ coordinates with $\mathrm{N}$ which can be derived from 


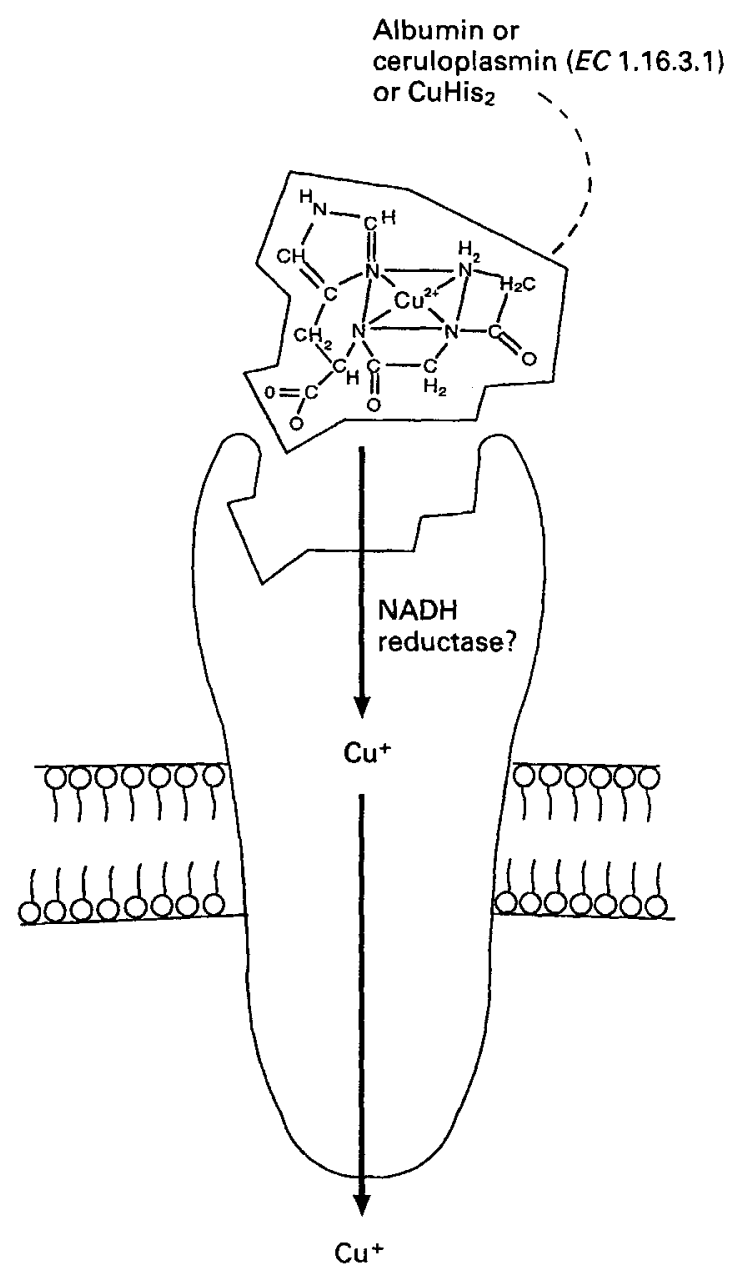

Fig. 1. A model for copper uptake by mammalian cell. The binding site on the carrier recognizes a $\mathrm{Cu}$-imidazole-nitrogen complex; the remainder of the binding moiety being irrelevant. Following binding, the cupric ion is reduced, possibly by a membrane-bound NADH reductase, dissociates from its nitrogenous complex and is transferred across the cell membrane. This model should not be taken to infer that the NADH reductase necessarily is the carrier itself. It should also be noted that other reducing agents, vitamin $\mathrm{C}$, for example, may also be able to act in a similar manner. $\mathrm{CuHis}_{2}$, $\mathrm{Cu}$-histidine complex.

histidine-imidazoles, $\alpha$-amino groups of amino acids, or $\mathrm{N}$ of peptide bonds. If the recognition epitope is small, just the $\mathrm{Cu}$-binding complex, then the membrane carrier would be able to accumulate and utilize $\mathrm{Cu}$ from a variety of substrates: $\mathrm{CuHis}_{2}, \mathrm{CuAlb}$, $\mathrm{CuHisAlb}$ or ceruloplasmin. Following binding, the $\mathrm{Cu}^{2+}$ is reduced to $\mathrm{Cu}^{+}$, possibly by a reductase or perhaps by vitamin $\mathrm{C}$, and then carried across the membrane into the cell (Fig. 1).

Clearly, this hypothesis is speculative, but it does have considerable heuristic value and fits the findings collected thus far, as well as explaining both hepatocyte and 
non-hepatocyte $\mathrm{Cu}$ uptake in terms of a single mechanism, the final substrate of which varies according to the relative concentration of the substrates rather than any genetic differences.

\section{CONCLUSIONS}

Clearly, there are many differences in the mechanisms involved in the transfer of Fe and $\mathrm{Cu}$ across the cell membrane. However, there are also important similarities. Both metals are carried on chelating molecules which are important in the recognition system. Both are taken up by carrier systems, although the types of system may be different. It is likely that both are reduced during the uptake process and it is almost certain that, if we apply the lessons learnt in Fe transport, we will rapidly understand more about the processes involved in the uptake of $\mathrm{Cu}$.

The author acknowledges support by the Wellcome Trust and support by the National Health and Medical Research Council of Australia and The Murdoch Institute, for much of his work reported in the present review.

\section{REFERENCES}

Aldred, A. R.. Grimes, A., Schreiber, G. \& Mercer, J. F. (1987). Rat ceruloplasmin. Molecular cloning and gene expression in liver, choroid plexus, yolk sac, placenta, and testis. Journal of Biological Chemistry 262, 2875-2878.

Appleton, D. \& Sarkar, B. (1971). The absence of specific copper(II)-binding site in dog albumin. Journal of Biological Chemistry 246, 5040-5046.

Baker, E., McArdle, H. J. \& Morgan, E. H. (1985). Transferrin-cell interactions; studies with erythroid, placental and hepatic cells. Proteins of Iron Storage and Transport, pp. 131-142 [G. Spik, J. Montreuil,

R. R. Crichton and J. Mazurier, editors]. Amsterdam: Elsevier.

Barnea, A., Cho, G. \& Hartter, D. E. (1988). A correlation between the ligand specificity for 67 copper uptake and for copper-prostaglandin E2 stimulation of the release of gonadotropin-releasing hormone from median eminence explants. Endocrinology 122, 1505-1510.

Barnes, G. \& Frieden, E. (1984). Ceruloplasmin receptors of erythrocytes. Biochemical and Biophysical Research Communications 125, 157-162.

Bierings, M. B. (1989). Placental iron uptake and its regulation. PhD Thesis, Erasmus University, Rotterdam.

Bierings, M. B., Adriaansen, H. J. \& van Dijk, J. P. (1988). Transferrin receptors on cyto- and in-vitro formed syncytiotrophoblast. Placenta $9,387-396$.

Bleil, J. D. \& Bretscher, M. S. (1982). Transferrin receptor and its recycling in HeLa cells. EMBO Journal 1, 351-355.

Blight, G. D. \& Morgan, E. H. (1987). Receptor mediated endocytosis of transferrin and ferritin by guinea pig reticulocytes; uptake by a common pathway. European Journal of Cell Biology 43, 260-265.

Booth, A. G. \& Wilson, M. J. (1981). Human placental coated vesicles contain receptor-bound transferrin. Biochemical Journal 196, 355-362.

Bowen, B. J. \& Morgan, E. H. (1987). Anaemia of the Belgrade rat; evidence for the defective membrane transport of iron. Blood 70, 38-44.

Breslow, E. (1964). Comparison of cupric ion binding sites in myoglobin derivatives and serum albumin. Journal of Biological Chemistry 239, 5040-5046.

Calabrese, L., Carbonaro, M. \& Musci, G. (1989). Presence of coupled trinuclear copper cluster in mammalian ceruloplasmin is essential for efficient electron transfer to oxygen. Journal of Biological Chemistry 264, 6183-6187.

Dameron, C. T. \& Harris, E. D. (1987a). Regulation of aortic CuZn-superoxide dismutase with copper. Biochemical Journal 248, 664-668.

Dameron, C. T. \& Harris, E. D. (1987b). Regulation of aortic CuZn-superoxide dismutase with copper. Ceruloplasmin and albumin re-activate and transfer copper to the enzyme in culture. Biochemical Journal 248, 669-675. 
Danks, D. M. (1988). Copper deficiency in humans. Annual Review of Nutrition 8, 235-257.

Darwish, H. M., Cheney, J. C., Schmitt, R. C. \& Ettinger, M. J. (1984). Mobilization of copper(II) from plasma components and mechanisms of hepatic copper transport. American Journal of Physiology 246, G72-G79.

Darwish, H. M., Hoke, J. E. \& Ettinger, M. J. (1983). Kinetics of Cu(II) transport and accumulation by hepatocytes from copper-deficient mice and the brindled mouse model of Menkes' disease. Journal of Biological Chemistry 258, 13621-13626.

Dautry-Varsat, A., Chiechanover, A. \& Lodish, H. F. (1983). pH and the recycling of transferrin during receptor-mediated endocytosis. Proceedings of the National Academy of Sciences, USA 80, 2258-2262.

de Jong, G., van Dijk, J. P. \& van Eijk, H. G. (1990). The biology of transferrin. Clinica Chimica Acta 190, $1-46$.

Douglas, G. C. \& King, B. F. (1990). Uptake and processing of ${ }^{125} \mathrm{I}$ labelled transferrin and ${ }^{59} \mathrm{Fe}$ labelled transferrin by isolated human trophoblast cells. Placenta 11, 41-57.

Frieden, E. (1980). Caeruloplasmin: a multi-functional metalloprotein of vertebrate plasma. Ciba Foundation Symposium 79, 93-124.

Gutteridge, J. M. (1983). Antioxidant properties of caeruloplasmin towards iron- and copper-dependent oxygen radical formation. FEBS Letters 157, 37-40.

Hanover, J. A., Beguinot, L., Willingham, M. C. \& Pastan, I. H. (1985). Transit of receptors for epidermal growth factor and transferrin through coated pits; analysis of the kinetics of receptor entry. Journal of Biological Chemistry 260, 15938-15945.

Harding, C., Heuser, J. \& Stahl, P. (1983). Receptor mediated endocytosis of transferrin and recycling of the transferrin receptor in rat reticulocytes. Journal of Cell Biology 997, 329-339.

Harris, D. I. M. \& Sass-Kortsak, A. (1967). The influence of amino acids on copper uptake by rat liver slices. Journal of Clinical Investigations 46, 659-677.

Herd, S. M., Camakaris, J., Chrison, R., Wookey, P. \& Danks, D. M. (1987). Uptake and effux of copper-64 in Menkes'-disease and normal continuous lymphoid cell lines. Biochemical Journal 247, 341-347.

Herve, M. (1985). Reaction of human ceruloplasmin and anion treated ceruloplasmin with diethyldithiocarbamate. Journal of Inorganic Biochemistry 25, 121-130.

Holmberg, C. G. \& Laurell, C.-B. (1947). Investigations in serum copper. I. Nature of serum copper and its relation to the iron binding protein. Acta Chemica Scandinavica 82, 944-950.

Holmberg, C. G. \& Laurell, C.-B. (1948). Investigations in serum copper. II. Isolation of the copper containing protein and description of some of its properties. Acta Chemica Scandinavica 2, 550-555.

Hopkins, C. R. (1983). Intracellular routing of transferrin and transferrin receptors in epidermoid carcinoma A431 cells. Cell 35, 321-330.

Hopkins, C. R. \& Trowbridge, I. S. (1983). Internalization and processing of transferrin receptor in human carcinoma A431 cells. Journal of Cell Biology $97,508-521$.

Iacopetta, B. J. \& Morgan, E. H. (1983). The kinetics of transferrin endocytosis and iron uptake from transferrin by rabbit reticulocytes. Joumal of Biological Chemistry 258, 9108-9115.

Jandl, J. H. \& Katz, J. (1963). The plasma-to-cell cycle of transferrin. Journal of Clinical Investigations 42, 314-326.

Karin, M. \& Mintz, D. (1981). Receptor mediated endocytosis of transferrin in developmentally totipotent mouse teratocarcinoma stem cells. Journal of Biological Chemistry 256, 3245-3252.

Katz, B. M. \& Barnea, A. (1990). The ligand specificity for uptake of complexed copper-67 by brain hypothalamic tissue is a function of copper concentration and copper:ligand molar ratio. Journal of Biological Chemistry 265, 2017-2021.

Lamparelli, R. D., Friedman, B. M., MacPhail, A. P., Bothwell, T. H., Phillips, J. I. \& Baynes, R. D. (1989). The fate of intravenously injected tissue ferritin in pregnant guinea pigs. British Journal of Haematology 72 , 100-105.

Lau, S. J. \& Sarkar, B. (1971). Ternary co-ordination complex between human serum albumin, copper(II) and histidine. Journal of Biological Chemistry 246, 5938-5943.

Lau, S. Y., Kruck, T. P. A. \& Sarker, B. (1974). Peptide molecule mimicking the copper(II) transport site of human serum albumin. Journal of Biological Chemistry 246, 5878-5884.

Laurie, S. H. \& Pratt, D. E. (1986). Copper-albumin: what is its functional role? Biochemical and Biophysical Research Communications 135, 1064-1068.

Linder, M. \& Moor, J. (1977). Plasma ceruloplasmin: evidence for its presence in and uptake by heart and other organs of the rat. Biochimica et Biophysica Acta 499, 329-336. 
Linder, M. C. (1991). Nutritional Biochemistry and Metabolism. New York: Elsevier.

McArdle, H. J., Douglas, A. J., Bowen, B. J. \& Morgan, E. H. (1985). The mechanism of iron uptake by the rat placenta. Journal of Cellular Physiology 124, 446-450.

McArdle, H. J., Douglas, A. J. \& Morgan, E. H. (1984a). Uptake of transferrin and iron by cultured rat placental cells. Journal of Cellular Physiology 122, 405-409.

McArdle, H. J., Douglas, A. J. \& Morgan, E. H. (1984b). Transferrin binding by microvillar vesicles isolated from rat placenta. Placenta $5,131-138$.

McArdle, H. J. \& Erlich, R. (1991). Copper uptake and transfer to the mouse fetus during pregnancy. Journal of Nutrition 121, 208-214.

McArdle, H. J., Gross, S. M. \& Danks, D. M. (1988). Uptake of copper by mouse hepatocytes. Journal of Cellular Physiology 136, 373-378.

McArdle, H. J., Gross, S. M., Danks, D. M. \& Wedd, A. G. (1990). Role of albumin's specific copper binding site in copper uptake by mouse hepatocytes. American Journal of Physiology 258, G988-G991.

McArdie, H. J., Guthrie, J. R., Ackland, M. L. \& Danks, D. M. (1987). Albumin has no role in the uptake of copper by human fibroblasts. Journal of Inorganic Biochemistry 31, 123-131.

McArdle, H. J. \& van den Berg, G. J. (1991). Copper uptake by microvillar vesicles isolated from human term placenta. Journal of Physiology 438, 268P.

McClelland, A., Kuhn, L. C. \& Ruddle, F. H. (1984). The human transferrin receptor gene: genomic organisation and the complete primary structure of the receptor deduced from a cDNA sequence. Cell 39, 267-274.

Marceau, N. \& Aspin, N. (1972). Distribution of ceruloplasmin-bound 67Cu in the rat. American Journal of Physiology 222, 106-112.

Marceau, N. \& Aspin, N. (1973). The intracellular distribution of the radiocopper derived from ceruloplasmin and albumin. Biochimica et Biophysica Acta 293, 338-350.

Mehra, R. K. \& Bremner, I. (1983). Development of a radioimmunoassay for rat liver metallothionein-I and its application to the analysis of rat plasma and kidneys. Biochemical Journal 213, 459-465.

Messerschmidt, A. \& Huber, R. (1990). The blue oxidases, ascorbate oxidase, laccase and ceruloplasmin: modelling and structural relationships. European Journal of Biochemistry 187, 341-352.

Morgan, E. H. (1981). Transferrin; biochemistry, physiology and clinical significance. Molecular Aspects of Medicine 4, 1-120.

Morgan, E. H. \& Appleton, T. C. (1969). Autoradiographic localisation of 125I-labelled transferrin in rabbit reticulocytes. Nature 223, 1371-1372.

Morley, C. G. D. \& Bezkorovainy, A. (1985). Cellular iron uptake from transferrin: is endocytosis the only mechanism? International Journal of Biochemistry 17, 553-564.

Musgrove, E., Rugg, C., Tayior, I. \& Hedley, D. (1984). Transferrin receptor expression during exponential and plateau phase growth of human tumour cells in culture. Journal of Cellular Physiology 118, 6-12.

Neumann, P. Z. \& Sass-Kortsak, A. (1967). The state of copper in human serum; evidence for an amino acids bound fraction. Journal of Clinical Investigations 46, 646-660.

Omary, M. B. \& Trowbridge, I. S. (1981). Biosynthesis of the human transferrin receptor in cultured cells. Journal of Biological Chemistry 256, 12888-12892.

Orena, S. J., Goode, C. A. \& Linder, M. C. (1986). Binding and uptake of copper from ceruloplasmin. Biochemical and Biophysical Research Communications 139, 822-829.

Owen, C. A. J. (1980). Copper and hepatic function. Ciba Foundation Symposium 79, 267-282.

Page, M. A., Baker, E. \& Morgan, E. H. (1984). Transferrin and iron uptake by primary cultures of rat liver cells. American Journal of Physiology 246, G26-G33.

Paterson, S., Armstrong, N., Iacopetta, B. J., McArdle, H. J. \& Morgan, E. H. (1984). Intravesicular pH and iron uptake by immature erythroid cells. Journal of Cellular Physiology 120, 225-232.

Pearse, B. M. F. (1982). Coated vesicles from human placenta carry ferritin, transferrin and immunoglobulin G. Proceedings of the National Academy of Sciences, USA 79, 451-455.

Percival, S. S. \& Harris,. E. D. (1988). Specific binding of ceruloplasmin to K562 cells. Journal of Trace Elements in Experimental Medicine 1, 63-70.

Percival, S. S. \& Harris, E. D. (1989). Ascorbate enhances copper transport from ceruloplasmin into human K562 cells. Journal of Nutrition 119, 779-784.

Percival, S. S. \& Harris, E. D. '(1990). Copper transport from ceruloplasmin; characterisation of the cellular uptake mechanism. American Journal of Physiology 258, C140-C146.

Rakhit, G. \& Sarkar, B. (1981). Electron spin resonance study of the copper (II) complexes of human and dog serum albumins and some peptide analogs. Journal of Inorganic Biochemistry 15, 233-241. 
Rao, K., van Renswoude, J., Kempf, C. \& Klausner, R. D. (1983). Separation of Fe(III) from transferrin in endocytosis. Role of the acidic endosome. FEBS Letters 160, 213-216.

Saenko, E. L. \& Yaropolov, A. I. (1990). Studies on receptor interaction of ceruloplasmin with red blood cells. Biochemistry International 20, 215-225.

Schmitt, R. C., Darwish, H. M., Cheney, J. C. \& Ettinger, M. J. (1983). Copper transport kinetics by isolated rat hepatocytes. American Journal of Physiology 244, G183-G191.

Stevens, M. D., Di Silvestro, R. A. \& Harris, E. D. (1984). Specific receptor for ceruloplasmin in membrane fragments from aortic and heart tissues. Biochemistry 23, 261-266.

Sun, I. L., Navas, P., Crane, F. L., Morro, D. J. \& Low, H. (1987). NADH diferric transferrin reductase in liver plasma membrane. Journal of Biological Chemistry 262, 15915-15921.

Trinder, D., Batey, R. G., Morgan, E. H. \& Baker, E. (1990). Effect of cellular iron concentration on iron uptake by hepatocytes. American Journal of Physiology 259, G611-G617.

Trowbridge, I. S. \& Omary, M. B. (1981). Human cell surface glycoprotein related to cell proliferation is the receptor for transferrin. Proceedings of the National Academy of Sciences, USA 78, 3039-3043.

Turkewitz, A. P., Schwartz, A. L. \& Marrison, A. C. (1988). A pH dependent reversible conformation transition of the human transferrin receptor leads to self-association. Journal of Biological Chemistry 263, 1609-1615.

van den Berg, G. J., Kroon, J. J., Wijburg, F. A., Sinjorge, K. M. C., Herzberg, N. H. \& Bolhuis, P. A. (1990a). Muscle cell cultures in Menkes' disease; copper accumulation in myotubes. Journal of Inherited Metabolic Diseases 13, 207-211.

van den Berg, G. J. \& van der Hamer, C. J. A. (1984). Trace metal uptake in liver cells. 1. Influence of albumin in the medium on the uptake of copper by hepatoma cells. Journal of Inorganic Biochemistry 22 , $73-84$.

van den Berg, G. J., van Wouwe, J. P. \& Beynen, A. C. (1990b). Ascorbic acid supplementation and copper status in rats. Biological Trace Element Research 23, 165-172.

van Renswoude, J., Bridges, K. R., Harford, J. B. \& Klausner, R. D. (1982). Receptor mediated endocytosis of transferrin and uptake of iron in K562 cells. Identification of a non-lysosomal compartment. Proceedings of the National Academy of Sciences, USA 79, 6186-6190.

Weiner, A. L. \& Cousins, R. J. (1980). Copper accumulation and metabolism in primary monolayer culture of rat liver parenchymal cells. Biochimica et Biophysica Acta 629, 113-125.

Weiner, A. L. \& Cousins, R. J. (1983). Hormonally produced changes in caeruloplasmin synthesis and secretion in primary cultured rat hepatocytes. Relationship to hepatic copper metabolism. Biochemical Journal 212, 297-304.

Weiss, K. C. \& Linder, M. C. (1985). Copper transport in rats involving a new transport protein. American Journal of Physiology 249, E77-E88.

Wiley, H. S. \& Kaplan, J. (1984). Epidermal growth factor rapidly induces a redistribution of transferrin receptor pools in human fibroblasts. Proceedings of the National Academy of Sciences, USA 81, 7456-7460.

Winyard, P. G., Hider, R. C., Brailsford, S., Drake, A. F., Lunec, J. \& Blake, D. R. (1989). Effects of oxidative stress on some physiochemical properties of caeruloplasmin. Biochemical Journal 258, 435-445.

Wirth, P. L. \& Linder, M. C. (1985). Distribution of copper among components of human serum. Journal of the National Cancer Institute 75, 277-284.

Wong, C. T., McArdle, H. J. \& Morgan, E. H. (1987). Effect of iron chelators on placental uptake and transfer of iron in the rat. American Journal of Physiology 252, C477-C482. 